\title{
Antitumor activity of antimicrobial peptides against U937 histiocytic cell line
}

\author{
Patrycja Koszałka ${ }^{1}$, Elżbieta Kamysz², Magdalena Wejda', Wojciech Kamysz ${ }^{3}$ and \\ Jacek Bigda ${ }^{1}$
}

1Department of Cell Biology, Faculty of Medical Biotechnology, Medical University of Gdansk, Gdańsk, Poland; 2 Faculty of Chemistry, University of Gdansk, Gdańsk, Poland; '3Department of Inorganic Chemistry, Faculty of Pharmacy, Medical University of Gdansk, Gdańsk, Poland

\begin{abstract}
We investigated cytotoxic activity of antimicrobial peptides of different origin (both naturally occurring and synthetic), structure and known mechanisms of action against human histiocytic lymphoma cell line U937. The strongest cytotoxic activity against U937 cell line was shown by Pexiganan MSI-78, followed by Citropin 1.1, Protegrin 1 and a synthetic lipopeptide, $\mathrm{N}$-a-palmitoylL-lysyl-L-lysine amide (Pal-Lys-Lys- $\mathrm{NH}_{2}$ ). The cytotoxic activity of the peptides was more dependent on the time of incubation than concentration. Only for the lipopeptide, whose mode of action was restricted to disruption of electric potential of the cell membrane, the correlation between cytotoxicity and concentration was almost linear. The high cytotoxicity of Pexiganan MSI-78, Protegrin 1 and the lipopeptide could be basically explained by their membranolytic activity leading to necrosis. However, in the case of Citropin 1.1, the cell membrane integrity was disrupted only slightly and independently of the peptide concentration. Therefore, some other mechanism of action might be responsible for its strong dose-dependent cytotoxic activity, e.g., membranolytic activity leading to apoptosis. Furthermore, TNF-a production due to LPS (lipopolysaccharide) stimulation was suppressed by the presence of Citropin 1.1, Pexiganan MSI-78 or Protegrin 1, but not by Buforin 2 or the lipopeptide. Our experiments have shown that cytotoxic activity is not limited to some specific molecular structure of a peptide, but rather to the length of the peptide chain as it is likely to affect the efficiency of the tumor cell membrane disruption and interaction with LPS.
\end{abstract}

Keywords: U937 cells, antimicrobial peptides, lipopeptide

Received: 25 August, 2010; 28 December, 2010; accepted: 24 January, 2011; available on-line: 14 March, 2011

\section{INTRODUCTION}

Antimicrobial peptides (AMPs) constitute an evolutionarily conserved part of the innate immune defense mechanism found in a wide range of prokaryotic and eukaryotic organisms. They are active against bacteria, fungi, viruses and also take part in anti-tumor response making them promising candidates for therapeutic use (Lehrer \& Ganz, 1999; Reddy et al., 2004; Dubin et al., 2005). Over 1000 AMPs have already been isolated and characterized at the level of their primary structure (Bulet et al., 2004). Most of these naturally occurring peptides are generally 12 - to 50-amino acid long, have cationic properties, meaning that they have an overall positive net charge at physiological $\mathrm{pH}$, and fold into a variety of different structures, including $\alpha$-helices, $\beta$-sheets, extended helices, hairpins and loops. They can also adopt an amphipathic structure with a hydrophobic and a hydrophilic side (Bulet et al., 2004).

Their general mode of action is disruption of the cell membrane, in which their tendency to form amphipathic structures is believed to be pivotal by facilitating their interaction and insertion into the membrane (Oren \& Shai, 1998; Cudic, 2002). As they are generally cationic, they can be drawn electrostatically to the target membrane and accumulate on the surface. When a critical concentration of AMPs is reached, some conformational changes occur leading mainly to the formation of ion channels or aqueous pores and resulting in the death of the cell through hypoosmotic lysis (Shai, 1999). Although most of the AMPs seem to act mainly at the membrane level, their translocation into the cytoplasm is not uncommon and leads to intracellular changes including inhibition of protein or DNA synthesis (Boman et al., 1993; Reddy et al., 2004). Some AMPs, for instance Buforin 2, can even lack the ability to disrupt cell membrane and instead form non-permeabilizing pore-like structures that allow translocation of the peptide into the cytoplasm without cell lysis (Park et al., 1996; Kobayashi et al., 2004).

Most AMPs have some level of selectivity towards specific target cells, mainly towards prokaryotic ones. It is based on a complex blance of many different biophysical properties of AMPs such as secondary structure, overall charge and hydrophobicity as well as many different biophysical properties of the target cell membranes, such as, for instance, its phospholipid composition, curvature or the presence of cholesterol (Polozov et al., 1997; Matsuzaki et al., 1998; Shai, 1999; Wu et al., 1999; Bradshaw, 2003). It also leads to enhanced sensitivity of tumor cells to the lytic action of AMPs, due to the differences in composition of the cell membrane between tumor and normal cells and the disturbed cell membrane asymmetry in the former. The outer leaflet of the cell membrane of tumor cells contains negatively charged phosphatidylserine (PS) (3-9\% of the total membrane phospholipids) in contrast to normal cells in which PS is localized exclusively to the inner leaflet of the membrane (Utsugi et al., 1991). The negative charge of the

e-mail: pkosz@gumed.edu.pl

Abbreviations: AMPs, antimicrobial peptides; CTL, cytotoxic T lymphocyte; FBS, fetal bovine serum; LPS, lipopolysaccharide; Pal-LysLys- $\mathrm{NH}_{2}, \mathrm{~N}$ - $\alpha$-palmitoyl-L-lysyl-L-lysine amide; TNF- $\alpha$, tumor necrosis factor-alpha 
tumor cell membrane is also increased by higher levels of O-glycosylated mucins (Carraway et al., 2007). The resulting higher negative net charge of the cell surface of tumor cells compared to normal cells contributes to the selective lytic activity of antimicrobial peptides. For instance, cecropins and magainins kill neoplastic cells at concentrations lower than those required to lyse normal cells such as peripheral blood lymphocytes (Cruciani et al., 1991; Moore et al., 1994). AMPs can also function as mediators of inflammation as they can affect epithelial and immune cells modulating, e.g., proliferation, angiogenesis, cytokine release, and chemotaxis (Beisswenger \& Bals, 2005) by binding to cellular receptors at low concentrations and activating signalling pathways (Koczulla \& Bals, 2003).

In this publication, we present a study on the cytotoxic activity of a variety of antimicrobial peptides of different origin, structure and known mechanisms of action as shown in Table 1 against one tumor cell line - a human histiocytic lymphoma cell line U937. We also investigated the antitumor activity of a synthetic lipopeptide $\mathrm{N}$ - $\alpha$-palmitoyl-L-lysyl-L-lysine amide (Pal-Lys-Lys- $\mathrm{NH}_{2}$ ) (Kamysz et al., 2007). As its carries only one fatty acid residue, it exhibits a reduced mitogenicity (Bessler et al., 1985). Its direct activity against tumor cells through simple disruption of the membrane electric potential (Epand et al., 1999; Avrahami \& Shai, 2004) was analyzed and used for comparison with a possibly more complicated mechanism of action of the other peptides analyzed. Such an approach should allow an analysis of the level of dependence between the cytotoxic activity of the antimicrobial peptides and their structure.

\section{MATERIALS AND METHODS}

Cell lines and peptides. The human myeloid leukemia cell line U937 cells were cultivated long-term as a suspension cell culture in RPMI1640 medium supplemented with 10\% FCS (Gibco, Gaithesburg, MD, USA), $1 \mathrm{mM}$ sodium pyruvate, $100 \mathrm{U} / \mathrm{ml}$ penicillin and $100 \mu \mathrm{g} / \mathrm{ml}$ streptomycin. TNF- $\alpha$-sensitive mouse A9 fibroblastic cell line (Wallach, 1984) cells were cultivated long-term in Dulbecco's modified Eagle's medium supplemented with 10\% FCS (Gibco, Gaithesburg, MD, USA), $100 \mathrm{U} / \mathrm{ml}$ penicillin, $100 \mu \mathrm{g} / \mathrm{ml}$ streptomycin and $2 \mathrm{mM}$ L-glutamine. Both cell lines were cultivated at $37^{\circ} \mathrm{C}$ in a humidified atmosphere containing $5 \% \mathrm{CO}_{2}$ and split $1: 4$ every 5 days.

The peptides included in this study were synthesized manually in a microwave reactor by the solid-phase method using the 9-fluorenylmethoxycarbonyl chemistry (Fmoc) (Fields, 1990). The completeness of each coupling reaction was monitored by the chloranil test. The peptides were cleaved from the solid support with trifluoroacetic acid (TFA) in the presence of water $(2.5 \%)$, and triisopropylsilane $(2.5 \%)$ as scavengers. The cleaved peptides were precipitated with diethyl ether and the cysteine-containing ones were oxidized with $0.1 \mathrm{M}$ iodine in methanol. The peptides were purified by highperformance liquid chromatography (HPLC). The crude lipopeptide was purified by solid-phase extraction by a previously described protocol (Kamysz et al., 2002). The resulting fractions of purity greater than 95\% were verified by HPLC or thin-layer chromatography (TLC) for the lipopeptide. The peptides were also analyzed by matrix-assisted laser desorption ionization-time of flight mass spectrometry (MALDI-TOF MS).
In vitro cytotoxicity assay. U937 cells were cultured in 96-well plates at a density of $1 \times 10^{5}$ cells (for the 6 -h assay) or $5 \times 10^{4}$ cells (for the 40 -h assay) per well with serial dilutions of AMPs in $0.1 \mathrm{ml}$ of complete RPMI1640 medium with $1 \%$ FBS and $1 \mathrm{mM}$ pyruvate. Cell viability was measured with the 3-[4,5-dimethylthiazol-2-yl]-2,5-diphenyltetrazolium bromide (MT'T) assay (Mosmann, 1983). The optical density of wells containing cells cultured without AMPs was assumed to represent $100 \%$ cell viability.

Determination of TNF- $\alpha$ concentration in cell culture supernatants. U937 cells were cultured in 24-well plates at a density of $5.2 \times 10^{5}$ cells per well with chosen dilutions of AMPs in $0.52 \mathrm{ml}$ of complete RPMI1640 medium with $1 \%$ FBS and $1 \mathrm{mM}$ pyruvate. When additional stimulation of $\mathrm{TNF}-\alpha$ production was needed, PMA and LPS at final concentrations of $100 \mathrm{ng} / \mathrm{ml}$ each were added. Cells were incubated at $37^{\circ} \mathrm{C}$ in $5 \% \mathrm{CO}_{2}$ for $6 \mathrm{~h}$. After incubation supernatants were collected and FBS was added to the final concentration of $10 \%$.

The TNF- $\alpha$ concentration was measured by a standard cytotoxic assay coupled with the neutral red uptake assay using TNF- $\alpha$-sensitive mouse A9 fibroblastic cell line (Wallach, 1984). A9 cells were incubated for $17 \mathrm{~h}$ with the analyzed cell culture supernatants at a dilution of $1: 1$ in culture medium with addition of cycloheximide (CHX) $(0.25 \mathrm{mg} / \mathrm{ml})$. The optical density of the wells containing cells not treated with the supernatant but treated with CHX was assumed to represent 100\% cell viability.

Trypan blue uptake assay. Cell membrane integrity of U937 cells treated with AMPs obtained from the 6-h assay (as above) was analyzed using trypan blue. Pelleted cells were suspended in $100 \mu \mathrm{l}$ of RMPI medium and $20 \mu \mathrm{l}$ of cell suspension was mixed with equal volume of the trypan blue solution $(0.4 \%$ in PBS; Sigma). After 5 min of incubation at room temperature, the cells were counted in a Neubauer Improved hemocytometer. The percentage of cells not stained blue, that is with an intact cell membrane, was calculated. As a control, cells not treated with AMPs were used.

Statistical analysis. Statistical analysis for the in vitro assays was performed using the Mann-Whitney U-test.

\section{RESULTS}

\section{The effect of AMPs on tumor cell line U937 viability in vitro}

The cytotoxic effect of the chosen AMPs was analyzed on the human histiocytic lymphoma cell line U937, a frequently used model in studies of TNF- $\alpha$-mediated cytotoxicity (Sundstrom \& Nilsson, 1976). All the peptides, with the exception of Buforin 2, were highly cytotoxic when incubated with tumor cells for $40 \mathrm{~h}$. After such a long incubation period with the AMPs' at $20 \mu \mathrm{g} /$ $\mathrm{ml}$, the cell viability was around $2 \%$ only, with no visible differences among the peptides. A decrease of the AMPs' concentration to $0.5 \mu \mathrm{g} / \mathrm{ml}$ did not substantially increase the viability level in the 40-h assay. Only in the case of Omiganan MBI-226 did the viability increase to $15 \%$ (not shown). This suggests a stronger dependence of the antitumor effect on the duration of the assay than on the concentration of the peptides for the concentration range studied. 
Table 1. AMPs used in experiments, their sequence, grouping according to characteristics of their molecular structure, and mechanism of action

\begin{tabular}{|c|c|c|}
\hline Name and sequence & $\begin{array}{l}\text { Grouping according to characteristics of } \\
\text { molecular structure }\end{array}$ & Known mode of action \\
\hline $\begin{array}{l}\text { Buforin } 2 \\
\text { TRSSRAGLQFPVGRVHRLLRK (Park } \\
\text { et al., 1996) }\end{array}$ & $\begin{array}{l}\text { linear, a-helical peptide forming amphipa- } \\
\text { thic helix distorted around Pro( } 11 \text { ) with a } \\
\text { flexible N-terminal region (Kobayashi et al., } \\
\text { 2004; Cho et al., 2008) }\end{array}$ & $\begin{array}{l}\text { forms and disintegrates non-permeabilizing pore- } \\
\text { like structure to translocate without cell lysis then } \\
\text { bind to DNA and RNA (Park et al., 1998; Kobayashi } \\
\text { et al., 2004) }\end{array}$ \\
\hline $\begin{array}{l}\text { Citropin 1.1 } \\
\text { GLFDVIKKVASVIGGL-NH }{ }_{2} \text { (Wegener } \\
\text { et al., 1999; Wabnitz et al., 1999) }\end{array}$ & $\begin{array}{l}\text { linear, a-helical peptide without cysteines } \\
\text { (Wegener et al., 1999; Wabnitz et al., 1999) }\end{array}$ & $\begin{array}{l}\text { forms a 'carpet' on the membrane surface follo- } \\
\text { wing 'carpet-like' model (Ambroggio et al., 2005; } \\
\text { Fernandez et al., 2009) }\end{array}$ \\
\hline $\begin{array}{l}\text { Demegen P-113 } \\
\text { AKRHHGYKRKFH-NH }{ }_{2} \text { (Paquette et } \\
\text { al., 1997) }\end{array}$ & $\begin{array}{l}\text { linear, a-helical peptide with a predomi- } \\
\text { nance of one or more amino acids - histi- } \\
\text { dine-rich (Paquette et al., 1997) }\end{array}$ & $\begin{array}{l}\text { translocates into cytosol in Candida albicans (Jang } \\
\text { et al., 2008) }\end{array}$ \\
\hline $\begin{array}{l}\text { Omiganan MBI-226 } \\
\text { ILRWPWWPWRRK-NH }{ }_{2} \text { (Isaacson, } \\
\text { 2003) }\end{array}$ & $\begin{array}{l}\text { linear, a-helical peptide with a predomi- } \\
\text { nance of one or more amino acids - tryp- } \\
\text { tophane-rich (Isaacson, 2003) }\end{array}$ & $\begin{array}{l}\text { induces membrane depolarization, inhibition of } \\
\text { macromolecular synthesis and cell death (Melo et } \\
\text { al., 2007) }\end{array}$ \\
\hline $\begin{array}{l}\text { Pexiganan MSI-78 } \\
\text { GIGKFLKKAKKFGKAFVKILKK-NH } \\
\text { (Jacob \& Zasloff, 1994) }\end{array}$ & $\begin{array}{l}\text { linear, a-helical peptide without cysteines } \\
\text { (Gottler \& Ramamoorthy, 2009) }\end{array}$ & $\begin{array}{l}\text { binds to the membrane surface, forms dimers that } \\
\text { assemble toroidal pores, but not barrel-stave pores } \\
\text { (Gottler \& Ramamoorthy, 2009) }\end{array}$ \\
\hline $\begin{array}{l}\text { Protegrin } 1 \\
\text { RGGRLCYCRRRFCVCVGR-NH } \\
\text { kryakov et al., 1993) }\end{array}$ & $\begin{array}{l}\beta \text {-sheet structure stabilized by disulphide } \\
\text { bridges (Gottler et al., 2008; Mani et al., } \\
\text { 2006) }\end{array}$ & $\begin{array}{l}\text { assembles } \beta \text {-barrel membrane pore structure form- } \\
\text { ing the core of a toroidal pore (Mani, 2006; Got- } \\
\text { tler, 2008) }\end{array}$ \\
\hline $\begin{array}{l}\text { Temporin A } \\
\text { FLPLIGRVLSGIL-NH } \text { (Simmaco et } \\
\text { al., 1996) }\end{array}$ & $\begin{array}{l}\text { linear, a-helical peptide without cysteines, } \\
\text { basic, highly hydrophobic (Simmaco et al., } \\
\text { 1996) }\end{array}$ & $\begin{array}{l}\text { forms a transmembrane pore via a barrel-stave } \\
\text { mechanism or forms a 'carpet' on the membrane } \\
\text { surface via the 'carpet-like' model (Oren \& Sahi, } \\
\text { 1998), is also chemotactic to phagocytes (Chen et } \\
\text { al., 2004) }\end{array}$ \\
\hline
\end{tabular}

To find differences in the antitumor activity between individual peptides we had to shorten the incubation period to $6 \mathrm{~h}$ only. This enabled us to demonstrate higher antitumor efficiencies of Citropin 1.1, Pexiganan MSI-78 and Protegrin 1 in the U937 cell line model as only those peptides, together with the Pal-Lys-Lys- $\mathrm{NH}_{2}$ lipopeptide, showed a strong cytotoxic effect in the shortened incubation time (Fig. 1). The lipopeptide, even with its strong ability to increase the permeability of the cell membrane (Avrahami \& Shai, 2004), was less cytotoxic than the other three peptides. Those four peptides were chosen for a detailed analysis of the dose-dependence of their antitumor effect in the 6-h assay together with Buforin 2 to demonstrate its lack of cytotoxic effect against this tumor cell line (Fig. 2). Pexiganan MSI-78 had the strongest antitumor effect among the three peptides.

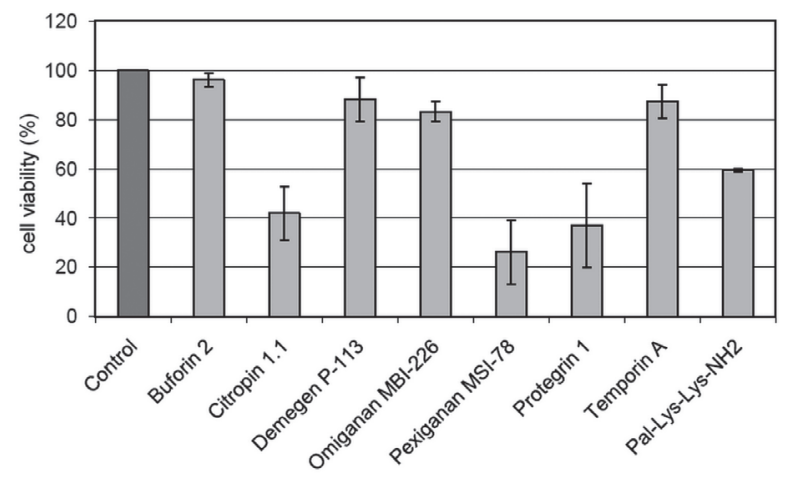

Figure 1. Cytotoxic effect of AMPs on U937 tumor cells AMPs at $20 \mu \mathrm{g} / \mathrm{ml}$ were added to cell culture for $6 \mathrm{~h}$, followed by MTT cytotoxicity assay. Data points represent averages of 3 independent MTT tests. The standard deviations are marked.
The difference was statistically significant for the doses of $20 \mu \mathrm{g} / \mathrm{ml}(P=0.01)$ and $10 \mu \mathrm{g} / \mathrm{ml} \quad(P=0.05)$. Although there was no difference in the cell culture viability at the dose of $20 \mu \mathrm{g} / \mathrm{ml}$ between Citropin 1.1 and Protegrin 1, the former showed a stronger antitumor efficiency at lower concentrations than did Protegrin 1 (statistically significant at $5 \mu \mathrm{g} / \mathrm{ml} ; P=0.05$ ). The cytotoxic activity of Pal-Lys-Lys- $\mathrm{NH}_{2}$ at $20 \mu \mathrm{g} /$ $\mathrm{ml}$ was similar to these of Citropin 1.1. and Protegrin 1 . However, in contrast to the other peptides, the lipopeptide cytotoxicity had an almost linear dependence on its concentration indicating a much simpler relationship between the concentration of the agent and its influence on the tumor cell. We also observed a lack of a cytotoxic activity of Buforin 2, which is unable to permanently disrupt the cell membrane (Kobayashi et al., 2004).

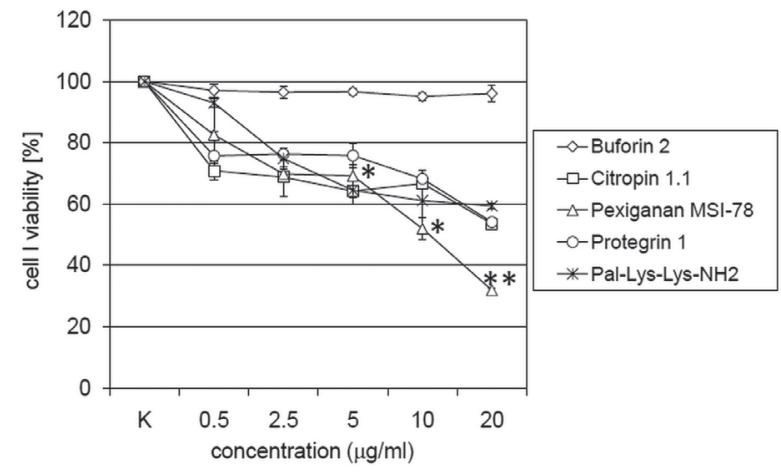

Figure 2. Dose-dependent cytotoxic effect of AMPs on U937 tumor cells

AMPs were added to cell culture for $6 h$, followed by MTT cytotoxicity assay. Data points represent averages of 6 independent MTT tests. The standard deviations are marked. ${ }^{*} P<0.05 ;{ }^{* *} P<0.01$. 


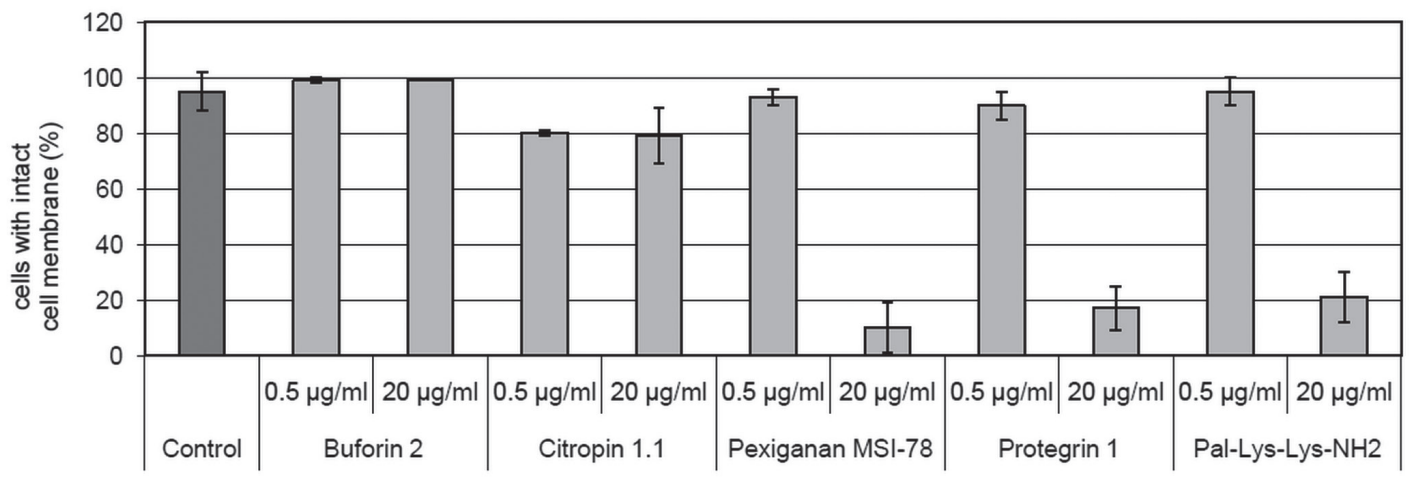

AMPs type and concentration $(\mu \mathrm{g} / \mathrm{ml})$

Figure 3. Dye uptake assay determining cell membrane integrity

Cell membrane integrity of U937 tumor cells after AMPs treatment for $6 \mathrm{~h}$ was checked using the trypan blue uptake assay. Low (0.5 $\mu \mathrm{g} /$ $\mathrm{ml})$ and high $(20 \mu \mathrm{g} / \mathrm{ml})$ concentrations of AMPs were used. Data points represent averages of 3 independent tests. The standard deviations are marked.

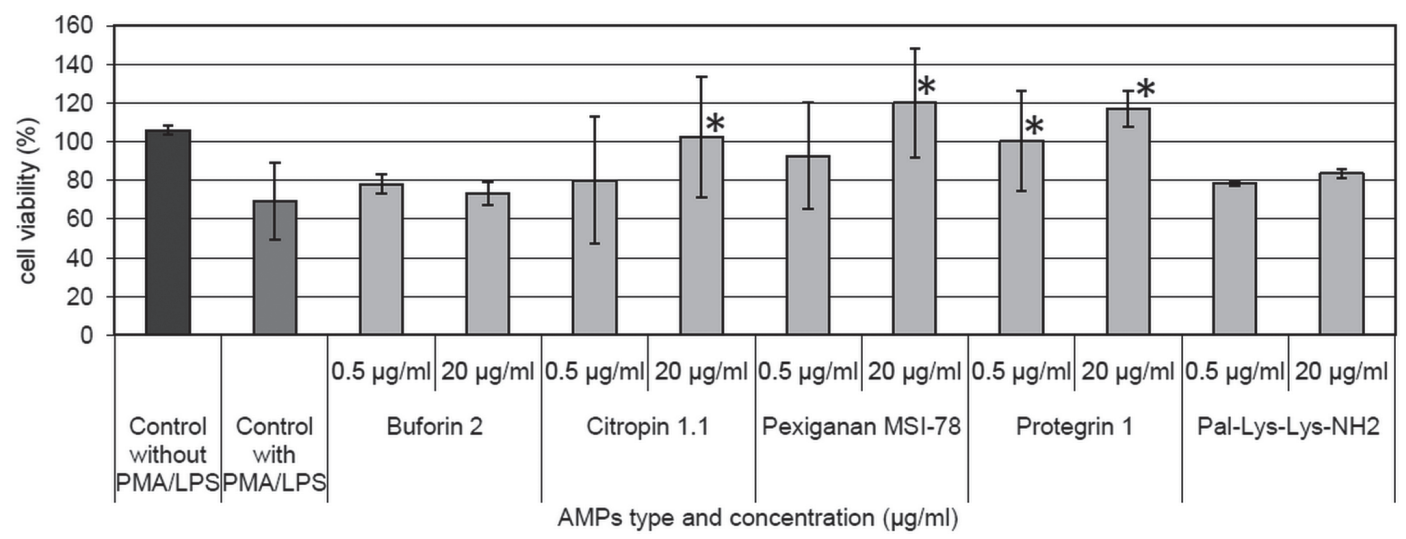

Figure 4. TNF- $a$ concentration in supernatants of U937 cell culture treated with AMPs for $6 \mathrm{~h}$ in the presence of LPS and PMA.

Low $(0.5 \mathrm{\mu g} / \mathrm{ml})$ and high $(20 \mu \mathrm{g} / \mathrm{ml})$ concentrations of AMPs were used. TNF-a concentration in supernatants was measured as the cytotoxic activity against TNF-a-sensitive A9 cell line using a 17-h NR assay in the presence of CHX. Control supernatants were from cell cultures not treated with AMPs and treated/not treated with LPS and PMA. Data for A9 cells not treated with any supernatant were taken as representing $100 \%$ viability (not shown on graph). Data points represent averages of 4-6 independent NR tests. The standard deviations are marked. ${ }^{*} P<0.05$.

\section{Influence of chosen AMPs on cell membrane integrity of U937 cells in vitro}

The best known mechanism of the action of AMPs is their membranolytic activity leading to necrosis. Microscopic observations have shown that cells seem to die of necrosis and apoptosis. We analyzed the mechanism of cell death using a dye uptake assay determining cell membrane integrity, which should be lost if cells die of necrosis. At the end of the 6-h cytotoxicity assay, the peptide-treated cells were stained with trypan blue a dye that migrates into the cytoplasm of the cell only when the integrity of its membrane is compromised. This assay showed (Fig. 3) that the antitumor activity of Pal-Lys-Lys-NH $\mathrm{N}_{2}$, Pexiganan MSI-78 and Protegrin 1 could satisfactorily be explained by their membranolytic activity leading to necrosis. This effect was clearly dosedependent. However, with Citropin 1.1, only a small percentage of the cells were dying of necrosis, and this level was similar both at high and low concentrations of the peptide. Consequently, in the case of Citropin 1.1., there should be an additional mechanism of action responsible for the antitumor activity of the peptide independent of its membranolytic activity and responsible for the dosedependent increase in its cytotoxicity. This mechanism needs further clarification.

\section{TNF-a release in supernatants of U937 cell line treated with AMPs}

To elucidate further the mechanism of the AMPs antitumor activity we examined the complicated relationship among LPS, TNF- $\alpha$ and AMPs, as elevated levels of TNF- $\alpha$ are often induced by inflammatory response elicited by cancer (Esper \& Harb, 2005), and some tumor cell lines, such as U937, can produce TNF- $\alpha$ upon stimulation with LPS and other immunomodulatory agents (Mander et al., 1997).

First, we checked TNF- $\alpha$ production by the U937 cell line treated with AMPs at 0.5 or $20 \mu \mathrm{g} / \mathrm{ml}$ for $6 \mathrm{~h}$. To determine of TNF- $\alpha$ concentrations in the cell culture supernatants we used the indicator cell line A9, mouse fibroblastic cells highly sensitive to the cytotoxic activity of $\mathrm{TNF}-\alpha$, especially in the presence of cycloheximide $(\mathrm{CHX})$ - an inhibitor of protein synthesis. There was no sign of detectable TNF- $\alpha$ levels in the supernatants of the cells treated or not treated with AMPs (not shown). The AMPs alone did not affect the viability of the A9 cell line, either (not shown). We concluded that the AMPs had no stimulatory effect on $\mathrm{TNF}-\alpha$ production by the U937 cell line without any additional stimulatory signal like that of LPS. 
Next, we stimulated the U937 cells with LPS and PMA in the presence of the AMPs using an identical time frame and AMPs concentration. The U937 cells released detectable levels of $\mathrm{TNF}^{-} \alpha$ into cell culture supernatant under these conditions (Fig. 4, controls) and the TNF- $\alpha$ production was suppressed in the presence of Citropin 1.1, Pexiganan MSI-78 or Protegrin 1 (Fig. 4). This effect was small for the AMPs at $0.5 \mu \mathrm{g} / \mathrm{ml}$, being statistically significant $(P=0.05)$ for Protegrin 1 only. It became statistically significant for all three peptides at $20 \mu \mathrm{g} / \mathrm{ml}(P=0.05)$. The highest activity in decreasing the level of TNF- $\alpha$ stimulated by LPS was shown by Protegrin 1, then by Pexiganan MSI-78, while the activity of Citropin 1.1 was substantially lower. The presence of Buforin 2 or Pal-Lys-Lys- $\mathrm{NH}_{2}$ did not affect the capacity of LPS to stimulate production of TNF- $\alpha$.

\section{DISCUSSION}

We examined the antitumor activity of a variety of antimicrobial peptides and its dependence on their structure and mechanism of action on one cell line, a human histiocytic lymphoma cell line U937, which is a frequently used model in studies of cytotoxicity (Sundstrom \& Nilsson, 1976). This approach simplified the analysis as the peptide selectivity towards a specific target cell is not only dependent on a multitude of biophysical properties of the AMPs, but also on those of the target cell membranes (Reddy et al., 2004).

It is thought that the amphipathicity of an AMP plays a pivotal role in its mechanism of action. The amphipathicity of a peptide depends, e.g., on its chain length, amino-acid sequence and the resultant net charge, and is enhanced upon formation of specific secondary structures such as $\alpha$-helices, $\beta$-hairpins or extended polyproline-like helices and is, of course, modulated by their concentration, ability to oligomerize and form different structures in the cell membrane (Shai, 1999; Chen et al., 2003; Papo \& Shai, 2003). Our experiments showed that the antitumor activity was not determined by some specific molecular structure of the peptide, as the cytotoxicity levels of Citropin 1.1 and Temporin A - two linear, $\alpha$-helical peptides of similar length (Simmaco et al., 1996; Wegener et al., 1999) were clearly different. Citropin 1.1 was highly cytotoxic to the U937 cell line, while Temporin $\mathrm{A}$ had almost no influence on its viability. Furthermore, Protegrin 1 containing a $\beta$-sheet as a dominant motif, showed similar cytotoxicity level as Citropin 1.1 at higher doses. This indicates that there is no simple link between the structure and the antitumor effect of those peptides. However, the highest cytotoxic activity of Pexiganan MSI-78 could be explained by its longer lenght of 22 amino acids (Jacob \& Zasloff, 1994). Such peptides, consisting of more than 20 amino-acid residues can form $\alpha$-helices of sufficient length to individually span a lipid membrane, thus enabling formation of different transmembrane structures in the target cell membrane than those formed by the shorter peptides. The transmembrane peptides can oligomerize into either 'barrel-stave' or toroidal pores, which work as non-selective channels disrupting the cell homeostasis and leading to cell death (Epand \& Vogel, 1999; Shai, 1999; Yang et al., 2001). Shorter peptides are more likely to work via formation of a 'carpet' on the membrane surface, in which they aggregate on the surface until a critical concentration is reached, at which point they solubilise or lyse the membrane in a detergent-like manner (Oren \& Shai,
1998; Epand \& Vogel, 1999; Shai, 1999). However, the length of the peptide is not the only critical factor, as shown by the low cytotoxic activity of Buforin 2 with its 21 amino-acid residues. It has been proposed that other factors, e.g., a peptide-lipid hydrophobic mismatch (de Planque et al., 2003) and the peptide concentration relative to threshold values (Aisenbrey et al., 2008) can play a role in the peptide cytotoxicity.

The effect on concentration was rather complex (Fig. 2) in the case of Citropin 1.1, Pexiganan MSI-78 and Protegrin 1 , as above $5 \mu \mathrm{g} / \mathrm{ml}$ the cytotoxicity of these peptides clearly increased, whereas at lower concentrations it was constant. Only for the lipopeptide PalLys-Lys- $\mathrm{NH}_{2}$ was its cytotoxicity almost linearly related to its concentration. We believe this simple relationship is due to the shortening of the peptide backbone and the presence of the palmitoyl residue (Kamysz et al., 2007). The cytotoxicity of all the peptides, with the exception of Buforin 2, was significantly increased by extending the incubation time in the cytotoxicity assay, even at a low concentration $(0.5 \mu \mathrm{g} / \mathrm{ml})$ (not shown). This suggests a stronger dependence of the antitumor effect on the duration of the attack of the antimicrobial peptides on the tumor cells than on their concentration. This time factor and its lack of influence on the activity of Buforin 2, the only peptide used in this work that does not permanently disrupt the cell membrane (Kobayashi et al., 2004), suggests that the antitumor activity of the peptides is mainly correlated with their ability to form pores in the cell membrane.

Our preliminary results obtained with the HL60 cell line derived from a human acute promyelocytic leukemia showed a similar, if slightly weaker, effect of the analyzed antimicrobial peptides, with Citropin 1.1, Pexiganan MSI-78 and Protegrin 1 affecting this cell line the most in the cytotoxicity assays. This suggests a universal link between the structure and cytotoxic effects of these peptides on various tumor cell lines.

We found that all the peptides which were highly cytotoxic to the U937 cell line disrupted the integrity of the cell membrane (Fig. 3). The best known mechanism of action of AMPs is their membranolytic activity leading to necrosis (Shai, 1999) and this mechanism can satisfactorily explain the antitumor activity of Pexiganan MSI-78, Protegrin 1 and Pal-Lys-Lys-NH$H_{2}$. In the case of Pexiganan MSI-78 and Protegrin 1, even though they adopt different secondary structures, they disrupt cell membrane through the same mechanism formation of toroidal pores (Mani et al., 2006; Gottler et al., 2009), in contrast to the other peptides used in this work (Table 1). Pal-Lys-Lys- $\mathrm{NH}_{2}$ as a lipopeptide acts directly through simple disruption of membrane electric potential (Epand \& Vogel, 1999; Avrahami \& Shai, 2004). However, in the case of Citropin 1.1, the situation is not so clear as the cell membrane integrity was disrupted only to a small extent and independently of the peptide concentration. Consequently, some other mechanism should be responsible for the strong and dose-dependent cytotoxic activity of this peptide, either a non-membranolytic one or another based on membranolytic activity leading to apoptosis (Mader \& Hoskin, 2006; Mader et al., 2007). The nature of this mechanism still needs to be elucidated.

Some peptides can induce non-membranolytic effects on target cells through binding to cellular receptors at low concentrations, activation of intracellular signalling pathways and stimulation of a variety of cellular functions (Koczulla \& Bals, 2003). For instance, some of the 
peptides, such as the neutrophil-derived heparin-binding protein (HBP), can stimulate the production of TNF- $\alpha$ by isolated monocytes (Heinzelmann et al., 1998) even without additional stimulation by, e.g., LPS. TNF- $\alpha$ is quite often induced in cancer patients because of the inflammatory response elicited by cancer leading to cachexia (Esper \& Harb, 2005). For this reason, we also decided to learn how our antibacterial peptides with the highest antitumor activity (and Buforin 2 as the least active one) affected $\mathrm{TNF}-\alpha$ production. It turned out that the AMPs analyzed had no direct stimulatory effect on $\mathrm{TNF}-\alpha$ production by the U937 cell line.

Moreover, we wanted to learn if they could affect the production of TNF- $\alpha$ induced in U937 cells by LPS and PMA stimulation. Infections are major causes of morbidity and mortality in patients with cancer (Smiley et al., 2005) and the presence of LPS can increase proliferation of some tumor cells, as well as increase their invasive potential (Harmey et al., 2002; Takabayashi et al., 2002). The cell line we used, the human histiocytic lymphoma cell line U937, is a frequently used model in studies of TNF- $\alpha$-mediated cytotoxicity and can generate TNF- $\alpha$ upon stimulation with LPS and PMA (Sundstrom \& Nilsson, 1976; Mander et al., 1997). Some AMPs can interact with LPS by strongly binding to LPS aggregates causing their dissociation, preventing LPS from binding to the carrier lipopolysaccharide-binding protein or to its $\mathrm{CD} 14$ receptor, thus reducing $\mathrm{TNF}-\alpha$ production by the cells (Rosenfeld et al., 2006). Some of our peptides indeed suppressed the level of TNF- $\alpha$ in cell culture supernatants of LPS-stimulated U937 cells, with a statistical significance for Protegrin 1 and a strong tendency for Citropin 1.1 and Pexiganan MSI-78 at low concentration $(0.5 \mu \mathrm{g} / \mathrm{ml})$, and in a statistically significant manner for all three at the higher concentration of $20 \mu \mathrm{g} / \mathrm{ml}$. PalLys-Lys- $\mathrm{NH}_{2}$ did not affect the ability of LPS to stimulate production of TNF- $\alpha$. This suggests that a longer peptide backbone is needed. A similar lack of effect also for Buforin 2 seems additionally to suggest that the ability of the peptides to form stable pores, and especially toroidal ones, like those of Protegrin 1 (Mani et al., 2006; Gottler et al., 2008), is in some way involved. One explanation could be the ability of such peptides to form strong aggregates with LPS, resulting in the reduction of TNF- $\alpha$ production due to the LPS stimulation. Further studies are needed to answer the question through what molecular mechanism the peptides influence TNF- $\alpha$ production due to LPS stimulation.

As AMPs begin showing their potential as highly selective antitumor drugs, even against diseases resistant to chemotherapy (Dubin et al., 2005; Mader \& Hoskin, 2006), this potential should be taken advantage of to solve the main problems in conventional anti-cancer chemotherapy: toxic side-effects, low response of slowgrowing tumors and dormant cells (Naumov et al., 2003) and the development of multi-drug resistance by tumor cells (Gottesman, 2002) even against anti-angiogenic drugs (Ferrara \& Kerbel, 2005). Understanding the relationships between AMPs structure and antitumor activity would be helpful in the development of synthetic peptides with the highest antitumor activity and selectivity and low side-effects, e.g., haemolysis. Our work showed that the cytotoxic activity of the analyzed peptides was not determined by some specific molecular structure, but was rather dependent on the length of the peptide chain, which is likely to affect the efficiency of the tumor cell membrane disruption and interaction with LPS. Therefore, some relationships between the structure and anti- tumor activity of antimicrobial peptides are likely to exist and deserve further elucidation.

\section{Acknowledgements}

Supported by a core fund of the Intercollegiate Faculty of Biotechnology UG-MUG DS/M000-40072-0.

\section{REFERENCES}

Aisenbrey C, Bechinger B, Gröbner G (2008) Macromolecular crowding at membrane interfaces: adsorption and alignment of membrane peptides. J Mol Biol 375: 376-385.

Ambroggio EE, Separovic F, Bowie JH, Fidelio GD, Bagatolli LA (2005) Direct visualization of membrane leakage induced by the antibiotic peptides: maculatin, citropin, and aurein. Biophys J 89: 1874-1881.

Avrahami D, Shai YA (2004) A new group of antifungal and antibacterial lipopeptides derived from non-membrane active peptides conjugated to palmitic acid. J Biol Chem 279: 12277-12285.

Beisswenger C, Bals R (2005) Functions of antimicrobial peptides in host defense and immunity. Curr Protein Pept Sci 6: 255-264.

Bessler WG, Cox M, Lex A, Suhr B, Wiesmüller KH, Jung G (1985) Synthetic lipopeptide analogs of bacterial lipoprotein are potent polyclonal activators for murine B lymphocytes. I Immunol 135: 1900-1905.

Boman HG, Agerberth B, Boman A (1993) Mechanisms of action on Escherichia coli of cecropin P1 and PR-39, two antibacterial peptides from pig intestine. Infect Immun 61: 2978-2984.

Bradshaw JP (2003) Cationic antimicrobial peptides. issues for potential clinical use. Biodrugs 17: 233-240.

Bulet P, Stöcklin R, Menin L (2004) Anti-microbial peptides: from invertebrates to vertebrates. Immunol Rev 198: 169-184.

Carraway KL 3rd, Funes M, Workman HC, Sweeney C (2007) Contribution of membrane mucins to tumor progression through modulation of cellular growth signaling pathways. Curr Top Dev Biol 78: $1-22$.

Chen F-Y, Lee M-T, Huang HW (2003) Evidence for membrane thinning effect as the mechanism for peptide-induced pore formation. Biophys J 84: 3751-3758.

Chen Q, Wade D, Kurosaka K, Wang ZY, Oppenheim JJ, Yang D (2004) Temporin A and related frog antimicrobial peptides use formyl peptide receptor-like 1 as a receptor to chemoattract phagocytes. I Immunol 173: 2652-2659.

Cho JH, Sung BH, Kim SC (2009) Buforins: Histone H2A-derived antimicrobial peptides from toad stomach. Biocbim Biophys Acta 1788: 1564-1569.

Cruciani RA, Barker JL, Zasloff M, Chen HC, Colamonici O (1991) Antibiotic magainins exert cytolytic activity against transformed cell lines through channel formation. Proc Natl Acad Sci USA 88: 3792-3796.

Cudic M, Otvos Jr L (2002) Intracellular targets of antibacterial peptides. Curr Drug Targets 3: 101-106.

de Planque MRR, Bonev BB, Demmers JAA, Greathouse DV, Koeppe RE 2nd, Separovic F, Watts A, Killian JA (2003) Interfacial anchor properties of tryptophan residues in transmembrane peptides can dominate over hydrophobic matching effects in peptide-lipid interactions. Biochemistry 42: 5341-5348.

Dubin A, Mak P, Dubin G, Rzychon M, Stec-Niemczyk J, Wladyka B, Maziarka K, Chmiel D (2005) New generation of peptide antibiotics. Acta Biochim Pol 52: 633-638.

Epand RM, Vogel HJ (1999) Diversity of antimicrobial peptides and their mechanisms of action. Biochim Biophys Acta 1462: 11-28.

Esper DH, Harb WA (2005) The cancer cachexia syndrome: a review of metabolic and clinical manifestations. Nutr Clin Pract 20: 369376.

Fernandez DI, Gehman JD, Separovic F (2009) Membrane interactions of antimicrobial peptides from Australian frogs. Biochim Biophys Acta 1788: $1630-1638$.

Ferrara N, Kerbel RS (2005) Angiogenesis as a therapeutic target. Nature 438: 967-974.

Fields GB, Noble RL (1990) Solid phase peptide synthesis utilizing 9-fluorenylmethoxycarbonyl amino acids. Int J Pept Protein Res 35: $161-214$.

Gottesman MM (2002) Mechanisms of cancer drug resistance. Ann Rev Med 53: 615-627.

Gottler LM, de la Salud Bea R, Shelburne CE, Ramamoorthy A, Marsh EN (2008) Using fluorous amino acids to probe the effects of changing hydrophobicity on the physical and biological properties of the $\beta$-hairpin antimicrobial peptide protegrin-1. Biochemistry 47: 9243-9250.

Gottler LM, Ramamoorthy A (2009) Structure, membrane orientation, mechanism, and function of pexiganan — A highly potent antimi- 
crobial peptide designed from magainin. Biochim Biophys Acta 1788: 1680-1686.

Harmey JH, Bucana CD, Lu W, Byrne AM, McDonnell S, Lynch C, Bouchier-Hayes D, Dong Z (2002) Lipopolysaccharide induced metastatic growth is associated with increased angiogenesis, vascular permeability and tumor cell invasion. Int J Cancer 101: 415-422.

Heinzelmann M, Mercer-Jones MA, Flodgaard H, Miller FN (1998) Heparin-binding protein (CAP37) is internalized in monocytes and increases LPS-induced monocyte activation. J Immunol 160: 55305536.

Isaacson RE (2003) MBI-226. Micrologix/Fujisawa. Curr Opin Investig Drugs 4: 999-1003.

Jacob L, Zasloff M (1994) Potential therapeutic applications of magainins and other antimicrobial agents of animal origin. Ciba Found Symp 186: $197-216$.

Jang WS, Li XS, Sun JN, Edgerton M (2008) The P-113 fragment of histatin 5 requires a specific peptide sequence for intracellular translocation in Candida albicans, which is independent of cell wall binding. Antimicrob Agents Chemother 52: 497-504.

Kamysz W, Kochańska B, Kędzia A, Ochocińska J, Maćkiewicz Z, Kupryszewski G (2002) Statherin SV2 and its analogue. Synthesis and evaluation of antimicrobial activity. Pol J Chem 76: 801-806.

Kamysz W, Silvestri C, Cirioni O, Giacometti A, Licci A, Della Vittoria A, Okroj M, Scalise G (2007) In vitro activities of the lipopeptides palmitoyl (Pal)-Lys-Lys- $\mathrm{NH}_{2}$ and Pal-Lys-Lys alone and in combination with antimicrobial agents against multiresistant grampositive cocci. Antimicrob Agents Chemother 51: 354-358.

Kobayashi S, Chikushi A, Tougu S, Imura Y, Nishida M, Yano Y, Matsuzaki K (2004) Membrane translocation mechanism of the antimicrobial peptide buforin 2. Biochemistry 43: 15610-15616.

Koczulla AR, Bals R (2003) Antimicrobial peptides current status and therapeutic potential. Drugs 63: 389-406.

Kokryakov VN, Harwig SS, Panyutich EA, Shevchenko AA, Aleshina GM, Shamova OV, Korneva HA, Lehrer RI (1993) Protegrins: leukocyte antimicrobial peptides that combine features of corticostatic defensins and tachyplesins. FEBS Lett 327: 231-236.

Lehrer RI, Ganz T (1999) Antimicrobial peptides in mammalian and insect host defense. Curr Opin Immunol 11: 23-27.

Mader JS, Richardson A, Salsman J, Top D, de Antueno R, Duncan R, Hoskin DW (2007) Bovine lactoferricin causes apoptosis in Jurkat T-leukemia cells by sequential permeabilization of the cell membrane and targeting of mitochondria. Exp Cell Res 313: 2634-2650.

Mader JS, Hoskin DW (2006) Cationic antimicrobial peptides as novel cytotoxic agents for cancer treatment. Expert Opin Investig Drugs 15: 933-946.

Mander T, Hill S, Hughes A, Rawlins P, Clark C, Gammon G, Foxwell B, Moore M (1997) Differential effects on TNF alpha production by pharmacological agents with varying molecular sites of action. Int I Immunopharmacol 19: 451-462.

Mani R, Cady SD, Tang M, Waring AJ, Lehrer RI, Hong M (2006) Membrane-dependent oligomeric structure and pore formation of a beta-hairpin antimicrobial peptide in lipid bilayers from solid-state NMR. Proc Natl Acad Sci 103: 16242-16247.

Matsuzaki K, Sugishita K, Ishibe N, Ueha M, Nakata S, Miyajima K, Epand RM (1998) Relationship of membrane curvature to the formation of pores by magainin 2. Biochemistry 37: 11856-11863.

Melo MN, Castanho MARB (2007) Omiganan interaction with bacterial membranes and cell wall models. Assigning a biological role to saturation. Biochim Biophys Acta 1768: 1277-1290.

Moore AJ, Devine DA, Bibby MC (1994) Preliminary experimental anticancer activity of cecropins. Pept Res 7: 265-269.

Mosmann T (1983) Rapid colorimetric assay for cellular growth and survival: application to proliferation and cytotoxicity assays. J Immunol Meth 65: 55-63.

Naumov GN, Townson JL, MacDonald IC, Wilson SM, Bramwell VH, Groom AC, Chambers AF (2003) Ineffectiveness of doxorubicin treatment on solitary dormant mammary carcinoma cells or latedeveloping metastases. Breast Cancer Res Treat 82: 199-206.
Oren Z, Shai Y (1998) Mode of action of linear amphipathic alphahelical antimicrobial peptides. Biopolymers 47: 451-463.

Papo N, Shai Y (2003) Exploring peptide membrane interaction using surface plasmon resonance: differentiation between pore formation versus membrane disruption by lytic peptides. Biochemistry 42: 458-466.

Paquette DW, Waters GS, Stefanidou VL, Lawrence HP, Friden PM, O 'Connor SM, Sperati JD, Oppenheim FG, Butchens LH, Williams RC (1997) Inhibition of experimental gingivitis in beagle dogs with topical salivary histatins. J Clin Periodontol 24: 216-222.

Park CB, Kim MS, Kim SC (1996) A novel antimicrobial peptide from Bufo bufo gargarizans. Biochem Biophys Res Commun 218: 408-413.

Park CB, Kim HS, Kim SC (1998) Mechanism of action of the antimicrobial peptide buforin II: buforin II kills microorganisms by penetrating the cell membrane and inhibiting cellular functions. Biochem Biophys Res Commun 244: 253-257.

Polozov IV, Polozova AI, Tytler EM, Anantharamaiah GM, Segrest JP, Woolley GA, Epand RM (1997) Role of lipids in the permeabilization of membranes by class $\mathrm{L}$ amphipathic helical peptides. Biochemistry 36: 9237-9245.

Reddy KVR, Yedery RD, Aranha C (2004) Antimicrobial peptides: premises and promises. Int J Antimicrob Agents 24: 536-547.

Rosenfeld Y, Papo N, Shai Y (2006) Endotoxin (lipopolysaccharide) neutralization by innate immunity host-defense peptides. I Biol Chem 281: 1636-1643.

Shai Y (1999) Mechanism of the binding, insertional destabilization of phospholipid bilayer membranes by helical antimicrobial and cell non-selective membrane lytic peptides. Biochim Biophys Acta 1462: 55-70.

Simmaco M, Mignogna G, Canofeni S, Miele R, Mangoni ML, Barra D (1996) Temporins, antimicrobial peptides from the European red frog Rana temporaria. Eur J Biochem 242: 788-792.

Smiley S, Almyroudis N, Segal BH (2005) Epidemiology and management of opportunistic infections in immunocompromised patients with cancer. Abstr Hematol Oncol 8: 20-30.

Sundstrom C, Nilsson K (1976) Establishment and characterization of a human histiocytic lymphoma cell line (U937). Int J Cancer 17: 565-577.

Takabayashi T, Takahashi N, Okamoto M, Yagi H, Sato M, Fujieda S (2009) Lipopolysaccharides increase the amount of CXCR4, and modulate the morphology and invasive activity of oral cancer cells in a CXCL12-dependent manner. Oral Oncol 45: 968-973.

Utsugi T, Schroit AJ, Connor J, Bucana CD, Fidler IJ (1991) Elevated expression of phosphatidylserine in the outer membrane leaflet of human tumor cells and recognition by activated human blood monocytes. Cancer Res 51: 3062-3066.

von Haussen J, Koczulla R, Shaykhiev R, Herr C, Pinkenburg O, Reimer D, Wiewrodt R, Biesterfeld S, Aigner A, Czubayko F, Bals R (2008) The host defence peptide LL-37/hCAP-18 is a growth factor for lung cancer cells. Lung Cancer 59: 12-23.

Wabnitz PA, Bowie JH, Wallace JC, Tyler MJ (1999) The citropin peptides from the skin glands of the Australian Blue Mountains tree frog Litoria citropa. Part 2: Sequence determination using electrospray mass spectrometry. Rapid Commun Mass Spectrom 13: 1724-1732.

Wallach D (1984) Preparations of lymphotoxin induce resistance to their own cytotoxic effect. I Immunol 132: 2464-2469.

Wegener KL, Wabnitz PA, Carver JA, Bowie JH, Chia BC, Wallace JC, Tyler MJ (1999) Host defence peptides from the skin glands of the Australian blue mountains tree-frog Litoria citropa. Solution structure of the antibacterial peptide citropin 1.1. Eur J Biochem 265: 627-637.

Wu M, Maier E, Benz R, Hancock RE (1999) Mechanism of interaction of different classes of cationic antimicrobial peptides with planar bilayers and with the cytoplasmic membrane of Escherichia coli. Biochemistry 38: 7235-7242.

Yang L, Harroun TA, Weiss TM, Ding L, Huang HW (2001) Barrelstave model or toroidal model? A case study on melittin pores. Biophys J 81: 1475-1785. 